\title{
PRESERVATION OF JAVANESE LANGUAGE ON GANJAR PRANOWO'S CONVERSATION IN PANDEMIC OF COVID-19
}

\author{
Umi Farichah ${ }^{1 *}$; Ani Rakhmawati²; Nugraheni Eko Wardani ${ }^{3}$ \\ ${ }^{1,2,3}$ Prodi Pendidikan Bahasa dan Sastra Daerah, Fakultas Keguruan dan Ilmu Pendidikan, Universitas Sebelas Maret \\ Jl. Ir. Sutami No. 36-A, Kentingan, Surakarta 57126, Indonesia \\ 'unduhbebas17@gmail.com; ${ }^{2}$ anirakhmawati@staff.uns.ac.id; ${ }^{3}$ nugraheniekowardani_99@yahoo.co.id
}

Received: $15^{\text {th }}$ September 2020/ Revised: $01^{\text {st }}$ November 2020/ Accepted: $02^{\text {nd }}$ November 2020

\author{
How to Cite: Farichah, U., Rakhmawati, A., \& Wardani, N. E. (2021). Preservation of Javanese language on \\ Ganjar Pranowo's conversation in pandemic of COVID-19. Humaniora, 12(1), 7-12. \\ https://doi.org/10.21512/humaniora.v12i1.6708
}

\begin{abstract}
The research aimed to see a relevance of the preservation of the Javanese language in Javanese conversations that Ganjar Pranowo carried out during the COVID-19 pandemic. The resulting data was about the level in the language that included word level, phrase level, and sentence level. Also, several manners, unggah ungguh, and ethics were produced that could become examples or role models for the people of Central Java. The research applied a qualitative method. The data source was the utterances contained in the uploads of Ganjar Pranowo in the form of video recordings that included primary data in the form of utterances or parts of spoken speech from various speeches and communications from the people of Central Java with Ganjar Pranowo. The results show that preservation of the Javanese language through conversations between leaders and the community has positive implications. This means that the preservation of the Javanese language is carried out optimally in the social sphere. This activity is well recorded and uploaded on social media, Ganjar Pranowo, a figure who has high credibility. The social sphere is an important component used to preserve Javanese language, culture, and traditions.
\end{abstract}

Keywords: language preservation, Javanese language, Javanese conversation, COVID-19 pandemic

\section{INTRODUCTION}

Language functionally describes grammar structures through its communicative functions and understands grammatical structures due to an adaptive process. In the adaptive process, the grammar is adapted to serve the communicative needs of its users. Language is a culture that is created and used by humans themselves as a means of communication. Language is also a means of self-expression and a means of communication as well as a means of showing self-identity (Chotimah, Untari, \& Budiman, 2019). Broadly speaking, communication is every form of someone's behavior, both verbal and nonverbal, which other people respond to. Communication includes a broader sense than just an interview. Every form of behavior expresses a certain message, so it is also a form of communication (Johnson in Supraktiknya, 2016).

The language itself can be said to be a formal system of signs that is subject to various grammatical rules to convey meaning. To understand the meaning of a speaker, the interlocutor must always interpret the utterances (Hardini, 2014). The view of language relates to language study in a pragmatic, cognitive, and interactive framework. Interaction alone cannot be separated from a conversation. Interaction in the conversation has the meaning of a series of behaviors that occur between two or more people, even several people who respond mutually. Therefore, the interactions that occur through conversation can mutually influence each other's behavior. Social interaction can be defined as dynamic social relationships. The occurrence of social interaction begins with communication in conversation and social contacts.

The conversations taking place in today's society are not as active and as much as they were before. Because right now, the world is grieving the outbreak of the coronavirus (COVID-19) which has 
infected mankind. The World Health Organization (WHO) has declared corona as a pandemic. Indonesia has also declared the COVID-19 pandemic a national disaster. The coronavirus pandemic that occurred has limited community activities. Now, there is such a thing as a new order in people's lives. The coronavirus outbreak has had a paralyzing impact on all aspects of life. This impact also affects all corners of the country in Indonesia, one of which is Central Java province.

The existence of the corona pandemic has made Ganjar Pranowo and the public more intense in interacting and having conversations, as seen from his Instagram social media. Starting from this conversation, there is a speech act between Ganjar Pranowo and the people of Central Java. The speech acts are dominated by regional languages (Javanese). The local language is a valuable asset of a nation (Widianto, 2018). Given that people in Central Java use more Javanese daily language. In line with Javanese characters and the characteristics of Javanese society, in studying language, one should not ignore language manners, especially Javanese culture which highly upholds the value of politeness. It also revitalizes the national identity, especially Javanese upload in speech acts (Adisti, 2018).

Speech acts are a pragmatic element that involves speakers and listeners or writers as well as the things that are discussed without leaving aside other contexts that accompany the speech act when it takes place (Akbar, 2018). Based on that description, the speech acts between Ganjar Pranowo and the community have indirectly shown the preservation of the Javanese language. The number one leader in Central Java speaks words with his citizens using the regional language (Java). As a determining criterion, the values of local wisdom can become a basis for the development of Javanese language preservation. Many regional cultural teachings regarding the values of wisdom in life are conveyed through a speech act statement. This shows that there is a system of signs or symbols as messages, whose meanings can be interpreted and applied in life in speech acts. This can also be said to be an implication of preserving Javanese tradition.

The preservation of Javanese tradition is increasingly visible with the existence of social media, especially Instagram, which is used by Ganjar Pranowo. Indirectly, social media plays an active role in this conservation. More and more people today are more active in playing social media, especially Instagram, making people remember and know the Javanese language. If used properly, social media will be beneficial in exposing traditional culture and traditions, which can be a means of education for the community. The preservation of Javanese tradition can be said to be a process of education and character building for society (Idrus, 2012). Culture itself can affect the strength of a person's character (Wijayanti \& Nurwianti, 2010).

The problem is the lack of learning to upload the Javanese language for the community, especially young people. Ganjar Pranowo's conversation in Javanese speech acts with the community can be an example of politeness for the community. It is mainly politeness in Javanese for the younger generation (millennial). It is undeniable that more and more young people currently perceive Javanese as an old, embarrassing, and outdated language. The conversations carried out by Ganjar Pranowo, which are uploaded via social media, Instagram, when viewed at a glance, showing politeness and learning how to unggah ungguh when talking to older people, the same age, younger, and children. In addition, it also shows how the young generation should behave when interacting with other people. It should be noted that the younger generation is now experiencing a moral crisis.

Research on language studies related to COVID-19 has been carried out by Listyarini and Nafarin (2020). It states that the discovery of five forms of deixis, namely personal deixis, place deixis, time deixis, discourse deixis, and social deixis. Based on the relevant research that has been done, research of language studies related to COVID-19 has only just found one. Research on language studies related to COVID-19 as a preservation of the Javanese language has not been found in previous research. So, the research has a novelty and a difference with previous research that discusses language related to COVID-19.

\section{METHODS}

This is a qualitative descriptive research using a pragmatic research approach. This qualitative descriptive research emphasizes the quality of the discussion of problems, not the quantity (results) of research calculations (Moleong, 2017). The data source in the research is the utterances contained in Ganjar Pranowo's upload in the form of video recordings from his social media (Instagram). Based on existing data sources, 32 records are generated. Each recording has a duration of approximately 00:59 seconds. The recording chosen is occurred during the corona pandemic and contains a Javanese conversation between Ganjar Pranowo and the community. Data is a special lingual phenomenon directly related to the problem in question, which in pragmatics is in the form of speech in oral or written form in certain contexts (Sudaryanto, 2015).

The technique used in studying data from oral data sources is the technique through the observation method. The listening technique is a technique of analyzing data by a researcher by listening to the use of language (Rohmadi, Kundharu, \& Hastuti, 2019). Then it is done by technique of notes and documentation. The data is validated using triangulation techniques.

\section{RESULTS AND DISCUSSIONS}

The following are forms of Javanese language preservation in the realm of the Central Javanese 
community with Ganjar Pranowo while visiting the Peterongan market. He uploads on his social media Instagram during the COVID-19 pandemic. The data in the video is first played by Ganjar and women in the Peterongan Semarang market. To see the Javanese preservation sentence, a transcription of the conversation is carried out.

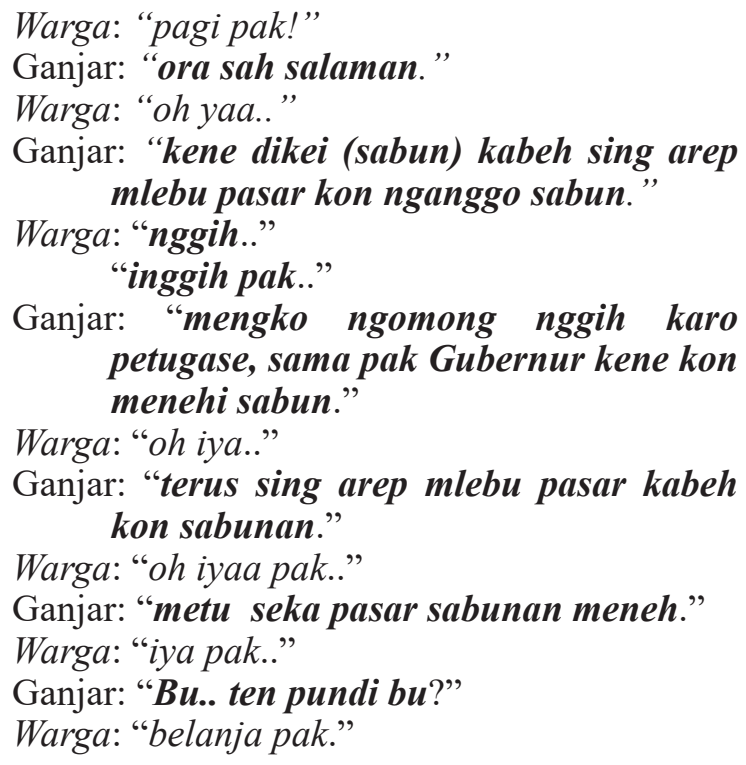

In the word fragment, there is a form of Javanese language preservation at the level of words, phrases, and sentences. At the word level, the preservation of the Javanese language can be seen in the fragments of the speech nggih 'yes', and nggih pak 'Yes, sir'. The words nggih and inggih are some of the words from the Javanese language included in the unggah ungguh base level, namely basa krama. Basa krama for Javanese people reflects politeness. In addition, the word is spoken in a conversation between a leader and the community, which has its charm. This can be called the preservation of the Javanese language. Meanwhile, preservation at the phrase level is not seen in the transcription above, namely the first video.

Furthermore, at the sentence level, it can be seen in Ora sah salaman (no need to shake hands), kene dikei (sabun) kabeh sing arep mlebu pasar kon nganggo sabun (here give (soap) everyone who wants to enter the market telling them to use soap..), mengko ngomong nggih karo petugase, sama pak Gubernur kene kon menehi sabun (say yes to the officer, said the governor here was told to give a soap), metu seka pasar sabunan meneh (after leaving the market, use soap again), and $B u$, ten pundi bu? (Where are you going?)

Sentence Ora sah salaman is a Javanese sentence that is included in the basa ngoko level. This sentence is included in the unggah-ungguh basa base harsh. Sentence ora sah salaman is pronounced by a leader and included in the category of command sentences addressed to the public during the COVID-19 pandemic. Then, the next sentence Kene dikei (sabun) kabeh sing arep mlebu pasar is also included in unggah-ungguh basa ngoko and is pronounced by a leader as a sentence of instruction to the community. Next, in the sentence mengko ngomong nggih karo petugase is included in unggah-ungguh basa ngoko which is refined. The sentence looks smooth because of the word nggih, which is a kind of basa krama. In addition, there is also the sentence metu seka pasar sabunan meneh, which is also included in unggahungguh basa ngoko. The sentence uttered by this leader is a command sentence. The last sentence in the first video is $B u$, ten pundi bu? which is the level of unggah-ungguh basa krama. It is said to be basa krama because it uses the words ten and pundi, which are included in the word category in krama.

These sentences can be said to be the preservation of the Javanese language. These sentences occur in the interaction between the Governor and residents in the market area. During the conversation process, a leader uses Javanese, even though there are residents who speak Indonesian. However, when residents respond in Indonesian, Ganjar as the leader who held the conversation still responds in Javanese. It can be said that it is a form of Javanese language preservation in society. Javanese is a communication tool that can attract the hearts of the people. In this case, language is used as a form of approach to discipline and socialize public health protection.

Ganjar cycling meets mothers who are shopping. The data in the second video is uploaded on the social media Instagram. Ganjar Pranowo involves interaction with the community that can be seen in this transcription.

Ganjar: "Ampun cedhak-cedhak."

Warga: "Nggih.. nggih.. nggih pak.."

Ganjar: "Adoh.. adoh.. nah walah pinter. nggih.." "Rada adoh.."

Warga: "Nggih pak.."

Ganjar: "Terus nek saged kemana-mana bawa untuk cuci tangan."

Warga: "Iyaa..."

Ganjar: "Dhuwit niki.. iki paling gampang nularke.. mulane njenengan nek bar niku cuci tangan.. bakule rada adoh.. nek blanja ngeten niki apik iki, malah rak sah nang pasar nggih ta."

Warga: "Nggih. kok boten wonten pertemuan nggih pak."

Ganjar: "Pertemuan napa?"

Warga: Ibu-ibu Dharma Wanita

Ganjar: "Ora sah sek, ora sah pertemuan sek."

Warga: "Iku prei?"

Ganjar: "Prei.. prei.. pertemuan online sak niki nggih."

Warga: "Nggih."

Ganjar: "Mangkih nyuwun tulung ten nggene ibu-ibu."

Warga: "Nggih.."

Ganjar: "Disosialisasikan aja cedhak-cedhak, cuci tangan sering-sering, sehat kabeh nggih".

Warga: "nggih.." 
The conversation fragment is a form of Javanese language preservation at the level of words, phrases, and sentences. At the word level, the preservation of Javanese is seen in the fragments of the utterances of nggih 'yes', prei 'holiday', dan Adoh 'far'. Nggih is included in the level of unggah-ungguh basa krama. So, it can be called the preservation of the Javanese language in the level of basa krama. Next, utterance prei which is in Javanese, is included in all levels of unggah-ungguh basa. So, it can be said as basa ngoko and krama. Then, utterance adoh, which is a word in unggah-ungguh basa ngoko. So, the level of words in the second video contains the levels of unggah-ungguh basa ngoko and krama.

Meanwhile, Javanese language preservation at the level of phrases can be seen in the passage such as inggih, Pak (Yes, Sir), nah walah pinter (Yes, that is smart), and rada adoh (far enough). The first utterance inggih, Pak is a speech that is included in unggahungguh basa krama level. The speech contains the meaning of being obedient to what is ordered. Second, nah walah pinter is included in unggah-ungguh basa. Third, rada adoh is a speech in unggah-ungguh basa ngoko level.

Furthermore, the level of sentences can be seen in the speech of ampun cedhak-cedhak (do not close). This speech is included in unggah-ungguh basa krama level because the word used in the sentence is one of the words in polite courtesy. Then, the utterance with the sentence terus nek saged kemana-mana bawa untuk cuci tangan (then, if you can, take it anywhere to wash your hands) contains words of krama, ngoko, and Indonesian. The sentences Dhuwit niki .. iki paling gampang nularke .. mulane njenengan nek bar niku cuci tangan .. Bakule rada adoh .. Nek blanja ngeten niki rak apik iki, malah boten usah nang pasar nggih ta (This money .. this is the easiest to transmit .. therefore wash your hands immediately .. the seller is a bit far away .. if shopping like this is good, you don't need to go to the market), nggih, kok boten wonten pertemuan nggih pak (how come there is no meeting, Sir), ora sah sek, ora sah pertemuan sek (you do not need to, you do not have to meet first), prei, prei, pertemuan online sak niki nggih (meetings are online now, huh), mangkih nyuwun tulung sepuluh nggene ibu-ibu (later, ask for help, ladies), and disosialisasikan aja cedhakcedhak, cuci tangan sering-sering, sehat kabeh nggih (socialize, do not be close, wash your hands often, all healthy) also contain krama and ngoko.

The Javanese language used by Ganjar Pranowo with the community mostly uses Javanese ngoko and krama madya. Ngoko language seems more familiar when used. Furthermore, usually, those who use basa ngoko are children with children, parents to young people, and leaders to subordinates. In the context of the conversation above, it can be seen that there are uploads by Ganjar. The uploads can be seen in the selection of sentences used to respond to public speech. Sometimes Ganjar uses ngoko, and sometimes he uses krama. All of this is included in the preservation of the Javanese language in terms of unggah ungguh.
The data in the third video shows Ganjar Pranowo's activities while visiting a mall in the city of Semarang. He visits Citra Land Mall Semarang in preparation for the New Normal. Speech that uses Javanese when having conversations with the community can be seen in this transcription.

Ganjar: "Semua yang jualan pakai masker, maskernya dipakai. Pakai ya jangan dilepas ya. Itu adek kecil aja pakai kok ya. Kalau ngobrol justru dipakai, nek ora idumu muncrat. Ini bahaya jangan disepelekan. Oke?"

Warga: "Oke."

Ganjar: "Saya tidak mau menutup toko. Tolong njenengan tertib. Oke ya?"

Warga: "Oke, Pak."

Ganjar: "Pilih nganggo masker apa tokone ditutup?"

Warga: "Pakai masker Pak."

Ganjar: "."

That conversation fragment shows a form of Javanese language preservation in level sentences. The levels of words and phrases are not visible in the chapters. Meanwhile, the sentence level can be seen in Nek ora idumu muncrat (If not later, your saliva will come out), Tolong njenengan tertib (Please keep your order), and pilih nganggo masker apa tokone ditutup? (Choose to wear a mask, or the shop will be closed?). The speech in the data has no arrangement in the form of words and phrases because Ganjar provides more input. Besides, people who are invited to speak also responded more in Indonesian. In the transcription, there is also unggah ungguh where Ganjar uses the correct language selection. It is different when Ganjar visits the market; he seems more familiar and more dominant in using the Javanese language frankly. This, there is knowledge in terms of ethics of selfplacement. All of this is included in the preservation of the Javanese language because Ganjar Pranowo does not directly contain the Javanese's basic principles and identity.

The data in the fourth video shows Ganjar Pranowo's activities when he resumes work normally in the Central Java provincial government. This interaction happens at the Central Java Provincial Government when he returns to work. Speech in Javanese when conversing with provincial government staff and employees can be seen in this transcription.

Ganjar: "Nanti kalau seumpama ada yang langsung melayani, kasih tabir." "Mika wae, mika, nek ora duwe ya plastik ki ora apa-apa. Plastik kaya warung." "Untuk anu sementara saja. Semua dikasih jarak." "Jangan ada yang sharing, diusahakan jangan ada yang sharing." "Sharing umpama laptope dan komputere nek isa usahakan tidak ada yang bareng-bareng." "Nah yang 


\author{
sering dipakai bareng-bareng sering \\ dilap pakai alkohol ya. Ngono.." "Nek \\ ketemu kancane ora usah nggablok- \\ nggablok. Pokoke itu sek yang ketat ya." \\ Warga: "Nggih.." \\ Ganjar: "Nggih.. wes matur nuwun."
}

In the conversation section, there is a form of Javanese language preservation at the level of words, phrases, and sentences. At the word level, Javanese language preservation can be seen in the fragment of the nggih 'yes' speech. Meanwhile, preservation at the level of phrases is not seen in the above passage. Then, the sentence level can be seen in Mika wae, mika, nek ora duwe ya plastik ki ora apa-apa. Plastik kaya warung (Just Mika, if you do not have plastic it is okay), Sharing umpama laptope dan komputere nek isa usahakan tidak ada yang bareng-bareng (Sharing if the laptop and computer if possible are not used together), and Nek ketemu kancane ora usah nggabloknggablok (If you meet a friend, you do not need to hit him). Based on the transcription results, it is revealed that there is the preservation of the Javanese language in office environments. Ganjar Pranowo tries to keep using Javanese in his official office. This can be said to be the preservation of the Javanese language because a leader is not ashamed to use his local language. The activities carried out by Ganjar Pranowo can be an example for staff and employees who work in the Central Java provincial government.

Apart from the things that have been explained earlier, the preservation of the Javanese language can also be seen in the existing ethics and unggah ungguh. There is a difference from previous data, where when Ganjar visits the market, meets women, visits the Mall, and is in the provincial government. If the data from the incident while in the provincial environment in the Ganjar administration looks relaxed and a little frankly speaking out; however, the response from the interlocutors is minimal. It is because the interlocutors still have feelings of shame and respect for Ganjar Pranowo, who is the Governor of Central Java.

The data in the fifth video shows the activities of Ganjar Pranowo, who is travelling around the city of Semarang on a bicycle and meeting the little mosque administrators. Cycling is one of Ganjar Pranowo's hobbies. Then he uses this hobby to disseminate information to the public about health protocols. The meeting between Ganjar Pranowo and the little mosque officials results in a conversation that can be seen in the transcription.

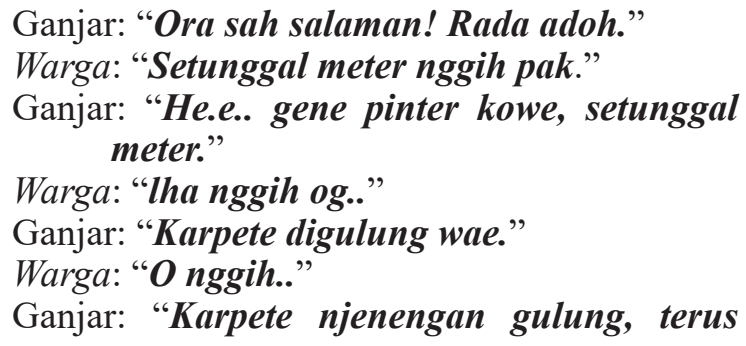

dipel nganggo sabun, soalnya itu kalau dipakai banyak orang kita gak pernah tau, terus langsung digulung nggih.. nek aku liwat rene digulung lho.. nggih.. oke"

Warga: "Siap!"

In this word fragment, there is a form of Javanese language preservation at the level of words, phrases, and sentences. The level of words as a preservation of the Javanese language can be seen in the fragment of the speech nggih 'Yes', He.e 'Yes'. Then at the phrase level, Javanese language preservation can be seen in the speech fragments such as rada adoh (It's a bit far), Lha nggih og (Yes, that's it). Furthermore, namely the level of sentences that can be seen in the passage such as ora sah salaman (No need to shake hands), Setunggal meter nggih, Pak (One meter, Sir), Karpete digulung wae, terus dipel nganggo sabun (Just roll up this carpet then mop the floor with soap), Terus langsung digulung nggih (then rolled up immediately), Nek aku liwat rene digulung lho (If I go through here, rolled it right away).

Based on these data described, it is found that there are three levels of complete Javanese preservation. The three levels are word level, phrase level, and sentence level. In addition to the discovery of levels in language, some conversations take place between Ganjar Pranowo and the people of Central Java, which results in almost all of them in Javanese. Starting from Ganjar, who uses Javanese, namely ngoko, makes people respond in Javanese too, and even responds by using krama language.

The activities that occur between Ganjar Pranowo and the community are one of the preservation of the Javanese language. The use of ngoko and krama language, which are unggah-ungguh basa (language manners), shows that people understand the ethics in placing themselves. This activity can be an example for the wider community. Moreover, the activities between Ganjar Pranowo and the community during the COVID-19 pandemic are uploaded on his social media, where he is very influential and has high credibility.

The activities carried out by Ganjar Pranowo are one of the tricks to attract people to comply with health protocols in the face of the COVID-19 pandemic that is currently hitting all countries in the world. These activities have indirectly become one of the things in preserving the Javanese language in this modern era. In addition to preserving the Javanese language, this activity is also ethics and unggah ungguh that can be learned and imitated by the people of Central Java in particular, as well as the wider community in general.

\section{CONCLUSIONS}

Based on the discussion, it can be concluded that the form of Javanese preservation in Javanese conversations conducted by Ganjar Pranowo during 
the COVID-19 pandemic results in several levels. This level includes word level, phrase level, and sentence level. Besides, several manners, unggah ungguh, and ethics are also produced that can be an example or role model for the wider community, especially the people of Central Java.

The preservation of the Javanese language through interactions and conversations between leaders and the community has positive implications. This means that the preservation of the Javanese language runs optimally in the social sphere. This activity is well recorded and uploaded on social media by Ganjar Pranowo, a figure who has high credibility. The social sphere is an important component used to preserve Javanese language, culture, and traditions. In line with that, the preservation of the Javanese language needs to be encouraged to stem the language shift that is increasingly running sporadically. Thus, the Javanese language will not experience disintegration during society or its native speakers.

\section{REFERENCES}

Adisti, A. R. (2018). Internalization of Javanese UnggahUngguh (etiquette) character in modern era through personality course at English Education department. Al-Ishlah: Jurnal Pendidikan, 10(2), 216-230. https://doi.org/10.35445/alishlah.v10i2.89.

Akbar, S. (2018). Analisis tindak tutur pada wawancara Putra Nababan dan Presiden Portugal (Kajian pragmatik). Jurnal Pendidikan Bahasa dan Sastra Indonesia, 1(1), 27-38. http://doi.org/10.29408/sbs. v1i1.792.

Chotimah, C., Untari, M. F. A., \& Budiman, M. A. (2019). Analisis penerapan unggah-ungguh bahasa Jawa dalam nilai sopan santun. International Journal of Elementary Education, 3(2), 202-209. https://doi. org/10.23887/ijee.v3i2.18529.

Hardini, I. (2014). Analisis pragmatik dalam wacana kampanye politik pemilihan Gubernur dan Wakil Gubernur Jawa Tengah periode 2013-2018. Jurnal Penelitian, 11(2), 301-316. https://doi.org/10.28918/ jupe.v11i2.426.

Idrus, M. (2012). Pendidikan karakter pada keluarga Jawa. Jurnal Pendidikan Karakter, 2(2), 118-130. https:// doi.org/10.21831/jpk.v0i2.1297.

Listyarini., \& Nafarin, S. F. A. (2020). Analisis deiksis dalam percakapan pada chanel Youtube Podcast Deddy Corbuzier bersama menteri kesehatan tayang Maret 2020. Jurnal Pendidikan Bahasa dan Sastra Indonesia, 9(1), 58-65. https://doi.org/10.15294/ jpbsi.v9i1.38628.

Moleong, L. J. (2017). Metodologi penelitian kualitatif edisi revisi. Bandung: PT Remaja Rosdakarya.

Rohmadi, M., Kundharu, S., \& Hastuti, S. (2019). Kajian pragmatik: Peran konteks sosial dan budaya dalam tindak tutur bahasa di Pacitan. Surakarta: Yuma Pustaka.

Sudaryanto. (2015). Metode dan aneka teknik analisis bahasa: Pengantar penelitian wahana kebudayaan secara Linguistis. Yogyakarta: Sanata Dharma University Press.

Supraktiknya, A. (2016). Tinjauan psikologis: Komunikasi antar pribadi. Yogyakarta: PT Kanisius.

Widianto, E. (2018). Pemertahanan bahasa daerah melalui pembelajaran dan kegiatan di sekolah. Jurnal Kredo, 1(2), 1-13.

Wijayanti, H., \& Nurwianti, F. (2010). Kekuatan karakter dan kebahagiaan pada suku Jawa. Jurnal Psikologi, 3(2), 114-122. 